\title{
PELIBATAN MAHKAMAH KONSTITUSI DALAM PERUBAHAN (ULANG) UUD 1945 YANG PARTISIPATIF MELALUI KOMISI KONSTITUSI
}

\author{
Oleh: Ni'matul \\ Huda \\ Fakultas Hukum Universitas Islam Indonesia Yogyakarta \\ Email : s3-hk@uii.ac.id
}

\begin{abstract}
currently reappears demands change as a result of the 1945 constitution as a evaluation 10 years after the 1945 constitution implementation after change. In this period there have been several issues submitted to the constitutional court about the testing of individual candidates in the presidential election, additional authority in perppu, constitutional complaint and the constitutional question by the court, the role of legislation optimalization dpd. This paper initiated a change the 1945 constitution more participatory through the constitutional commission more independent than the previous constitutional commission, with a mandate to prepare draft changes the 1945 constitution. Learning from the experience of various countries are also undergoing transition to democracy and constitutional reform, we should initiate to engage the court in a change in 1945 constitution.
\end{abstract}

Keywords: constitutional court, participatory, constitutional commission.

\begin{abstract}
Abstrak
Saat ini muncul kembali tuntutan perubahan (ulang) terhadap UUD 1945 sebagai hasil evaluasi 10 tahun lebih implementasi UUD 1945 pasca perubahan. Dalam kurun waktu tersebut sudah ada beberapa persoalan yang diajukan ke Mahkamah Konstitusi pengujian tentang calon perseorangan dalam pemilihan presiden, tambahan kewenangan Perppu, constitutional complaint dan constitutional question oleh MK, optimlisasi peran legislasi DPD, dan lain-lain. Tulisan ini menggagas perubahan (ulang) UUD 1945 yang lebih partisipatoris melalui Komisi Konstitusi yang lebih independen dibandingkan Komisi Konstitusi yang sebelumnya, dengan mandat menyiapkan draft perubahan (ulang) UUD 1945. Belajar dari pengalaman berbagai Negara yang juga mengalami transisi demokrasi dan reformasi konstitusi, ada baiknya kita menggagas untuk melibatkan MK dalam perubahan (ulang) UUD 1945.
\end{abstract}

Kata Kunci: Mahkamah Konstitusi, Partisipatif, Komisi Konstitusi

\section{A. Pendahuluan}

Di awal tahun 2008, Pemerintah dan DPR sepakat menyiapkan proses perubahan kelima UUD 1945 secara menyeluruh dengan segera membentuk panitia/komisi nasional. Kesepakatan itu diambil dalam rapat konsultasi di Istana Negara Jakarta, Jumat 25 Januari 2008. Konstitusi baru hasil perubahan tersebut nantinya diharapkan dapat digunakan pemerintahan baru hasil Pemilu 2009. Usulan Presiden Susilo Bambang Yudhoyono dan DPR untuk membentuk panitia/ komisi nasional yang mempersiapkan Perubahan v UUD 1945 memunculkan sikap yang beragam di masyarakat. Sebagian anggota MPR dan Forum Konstitusi kurang sependapat dengan usulan pembentukan panitia/komisi nasional tersebut.

Yustisia Vol.2 No.2 Mei-Agustus 2013
Mereka memandang kewenangan membentuk panitia/komisi tersebut ada pada MPR dan bukan domain Presiden (Kompas, 31 Januari 2008). Di sisi lain, sebagian anggota DPD dan kalangan ahli hukum tata negara mendukung gagasan Presiden dan DPR tersebut (Kompas, 1 Februari 2008).

Secara normatif memang kewenangan untuk melakukan perubahan UUD 1945 ada di tangan MPR, sehingga dipandang lebih tepat jika yang membentuk panitia/komisi nasional tersebut adalah MPR. Akan tetapi, usulan perubahan konstitusi tidak harus muncul dari MPR. Setiap warga negara yang memiliki kesadaran dan kepedulian terhadap masa depan bangsa ini berhak untuk mengusulkan perubahan konstitusi, dan selanjutnya dikaji kembali oleh MPR semua usulan yang masuk kepadanya. Semua anggota 
MPR RI sudah selayaknya segera mengkaji ulang berbagai usulan perubahan yang sudah diwacanakan di masyarakat, DPD, maupun berbagai pihak yang menaruh perhatian terhadap hasil amandemen UUD 1945. Berbagai ide penyempurnaan hasil amandemen UUD 1945 patut untuk diapresiasi secara konstruktif.

Hasil perubahan UUD 1945 yang dilakukan oleh MPR tahun 1999-2002 merupakan kontribusi positif terhadap upaya perbaikan sistem ketatanegaraan Indonesia ke depan. Dengan perubahan pasal-pasal tersebut, hasil perubahan MPR telah berhasil meletakkan sendi-sendi checks and balances, termasuk membatasi kekuasaan eksekutif, MPR telah berhasil mengubah dengan tegas tentang darimana kedaulatan diperoleh (locus of souvereignty). MPR yang terdiri anggota-anggota DPR dan anggota-anggota DPD merupakan realisasi demokrasi perwakilan. Sebagai lembaga negara, MPR hanya eksis ketika DPR dan DPD berada dalam sidang gabungan (joint session). Inovasi politik dan hukum melalui perubahan UUD 1945 oleh MPR era reformasi juga berkaitan dengan pemilihan langsung Presiden dan Wakil Presiden.

Sejumlah kalangan masyarakat menilai hasil Perubahan UUD 1945 oleh MPR jauh dari memuaskan karena 'elitis' dan kurang partisipatif. Perubahan UUD 1945 yang telah dilakukan MPR membuktikan, benturan kepentingan itu berpotensi menjadi perubahan konstitusi yang 'tambal sulam' dan tidak berorientasi kepentingan jangka panjang. Ketidaksempurnaan itu disebabkan karena dalam konteks perubahan UUD yang komprehensif, MPR sendiri sebenarnya adalah objek reformasi konstitusi yang seharusnya diatur kembali kewenangannya. Perubahan konstitusi seharusnya dilakukan oleh lembaga independen semacam Komisi Konstitusi dan dilakukan dengan melibatkan partisipasi masyarakat secara luas.

Sebagaimana diketahui, UUD 1945 telah menentukan prosedur perubahannya dalam Pasal 37 , akan tetapi tidak mengatur teknik perubahan yang harus dilakukan apakah dengan memakai cara Amerika Serikat atau Eropa Kontinental. Dan juga tidak menentukan secara tegas institusi negara yang berwenang melakukan perubahan terhadap UUD, tetapi dari Perubahan Pertama sampai dengan Perubahan Keempat, MPR beranggapan bahwa dirinyalah yang paling berwenang melakukan perubahan. Kritik atas kewenangan MPR ini, terutama dari kalangan yang menghendaki perubahan dilakukan oleh sebuah Komisi Konstitusi yang independen, tetapi dijawab oleh MPR dengan mengubah Pasal 3 UUD 1945 yang menambahkan kewenangan MPR untuk mengubah UUD, di samping kewenangan untuk menetapkan UUD (Perubahan Ketiga) (Ali Mukti Fajar, 2006 : 23).

Dari hasil kajian komprehensif yang dilakukan sejak Oktober 2003 sampai dengan April 2004 terhadap hasil perubahan UUD 1945 oleh MPR, Komisi Konstitusi berpendapat antara lain sebagai berikut (Komisi Konstitusi, 2004 : 122-127).

"Tidak dapat dipungkiri bahwa hasil perubahan UUD 1945 yang telah dilakukan MPR dalam beberapa hal mengandung kontradiksi, baik secara teoritis konseptual maupun praktek ketatanegaraan. Meskipun perubahan terhadap materi muatan meliputi lebih dari $50 \%$, dan terdiri dari 207 ayat, namun UUD 1945 masih tetap ada. Di samping itu juga terdapat inkonsistensi substansi baik yuridik maupun teoritik. Strukturisasi atau sistematisasi pasal-pasal tambahan yang tidak konsisten tersebut melahirkan inovasi politik dan hukum dari Komisi Konstitusi. Konstitusionalisasi yang dilakukan Komisi Konstitusi dibuktikan dengan lahirnya pasal-pasal tambahan. Sebagai contoh ialah pemilihan calon Presiden independen (Pasal 6A), pemberdayaan kewenangan DPD yang sejajar dengan DPR (Pasal 22C). Selain itu dalam penegakkan hukum juga terjadi inovasi. Hal ini terbukti yang selain dari Polri, juga diatur Kejaksaan dan Ombudsman (Pasal 24 D,E,F), pemilihan Kepala Daerah/Wakil Kepala Daerah secara langsung (Pasal 18 ayat (4)), asas retroaktif dalam kasus HAM berat (Pasal 28I), penyandang cacat (Pasal 34) dan kemerdekaan Pers yang dijamin dan diatur dalam undang-undang, keterlibatan rakyat dalam perubahan UUD 1945 dan Komisi Konstitusi (Pasal 37 ayat (7)).

Tiadanya kerangka acuan atau naskah akademik dalam melakukan perubahan UUD 1945 merupakan salah satu sebab timbulnya inkonsistensi teoritis dan konsep dalam mengatur materi muatan UUD. Hal ini juga berlaku terhadap prosedur perubahan UUD yang tidak melibatkan rakyat. Metode participatory yang dipergunakan oleh kebanyakan negara-negara modern, perlu digunakan dalam melakukan perubahan terhadap UUD."

Belakangan diketahui bahwa hasil Komisi Konstitusi yang dilaporkan kepada Badan Pekerja MPR ternyata kurang mendapat respon positif, bahkan kabarnya hasil kajian Komisi Konstitusi "ditolak" oleh MPR. Karena Komisi Konstitusi dinilai telah melampaui tugasnya yang mestinya hanya melakukan pengkajian secara komprehensif Perubahan UUD 1945 hasil karya MPR, tetapi malah mengusulkan perubahan terhadap hasil Perubahan UUD 1945 (Ni'matul Huda, 2008 : 225).

Rupanya antara Badan Pekerja (BP) MPR dengan Komisi Konstitusi terjadi perbedaan 
tafsir mengenai arti "pengkajian komprehensif Perubahan UUD 1945”. Komisi Konstitusi memberi makna yang luas, yaitu tidak hanya mencakup halhal seputar hasil Perubahan UUD 1945 yang telah dilakukan oleh MPR sebanyak empat tahap, tetapi juga mencakup pemikiran filosofis para founding fathers ketika membuat rumusan naskah UUD dalam sidang BPUPKI dan PPKI, sehingga hasil Komisi Konstitusi terdiri atas Naskah Akademik Hasil Pengkajian Perubahan UUD 1945 (Buku I) dan Usulan Perubahan Pasal-pasal UUD 1945 (Buku II) (Ali Mukti Fajar, 2006 : 63-64). Sementara itu, menurut BP MPR pengkajian secara komprehensif berarti melakukan kajian terhadap Perubahan UUD 1945, bukan melakukan kegiatan untuk membuat usulan perubahan terhadap Perubahan UUD 1945. Hasil Komisi Konstitusi diharapkan lebih mengarah kepada bagaimana mengimplementasikan Perubahan UUD 1945, antara lain dalam bentuk gagasan-gagasan ilmiah mengenai agenda pembentukan UU organik sebagai perangkat hukum pelaksanaan UUD 1945 agar dapat operasional dan memberi manfaat dalam peningkatan kualitas penyelenggaraan negara.

Belakangan muncul kembali tuntutan perubahan (ulang) terhadap UUD 1945 sebagai hasil evaluasi 10 tahun lebih implementasi UUD 1945 pasca perubahan. Dalam kurun waktu tersebut sudah ada beberapa persoalan yang diajukan ke Mahkamah Konstitusi pengujian tentang calon perseorangan dalam pemilihan presiden, tambahan kewenangan pengujian Perppu, constitutional complaint dan constitutional question oleh MK, optimalisasi peran legislasi DPD, dan lain-lain. Tulisan ini ingin menggagas perubahan (ulang) UUD 1945 yang lebih partisipatoris melalui Komisi Konstitusi yang lebih independen dibandingkan Komisi Konstitusi yang sebelumnya, dengan mandat menyiapkan draf perubahan (ulang) UUD 1945.

Sejak perubahan (ketiga) UUD 1945 telah lahir lembaga baru yang menjalankan fungsi kekuasaan kehakiman di luar Mahkamah Agung, yakni Mahkamah Konstitusi. Pasal 24C UUD 1945 memberikan mandat penuh kepada Mahkamah Konstitusi untuk menguji undang-undang terhadap Undang-Undang Dasar, memutus sengketa kewenangan lembaga negara yang kewenangannya diberikan oleh Undang-Undang Dasar, memutus perselisihan tentang hasil pemilihan umum. Mahkamah belum pernah memutus pembubaran partai politik dan memberikan putusan mengenai pendapat DPR bahwa Presiden dan/atau Wakil Presiden telah melakukan pelanggaran hukum berupa pengkhianatan terhadap negara, korupsi, penyuapan, tindak pidana berat lainnya, atau perbuatan tercela, dan/atau pendapat bahwa Presiden dan/atau Wakil Presiden tidak lagi memenuhi syarat sebagai Presiden dan/atau Wakil Presiden.

Sejak kehadirannya, ekspektasi masyarakat sangat tinggi terhadap Mahkamah Konstitusi, khususnya dalam pengajuan pengujian undangundang terhadap UUD 1945. Berbagai putusan progresif juga sudah ditorehkan dalam sejarah ketatanegaraan Indonesia melalui Mahkamah Konstitusi. Selain sebagai pengawal konstitusi (the guardian of the constitution) Mahkamah Konstitusi juga berfungsi sebagai penafsir konstitusi (the sole interpreter of the constitution).

Belajar dari pengalaman berbagai negara yang juga mengalami transisi demokrasi dan reformasi konstitusi, ada baiknya kita menggagas untuk melibatkan Mahkamah Konstitusi dalam perubahan (ulang) UUD 1945. Di samping itu, perjalanan \pm 11 tahun reformasi konstitusi adalah waktu yang cukup untuk mengkaji ulang sistem yang kita terapkan saat ini.

Adapun permasalahan yang diajukan dalam penelitian ini: pertama, apa urgensi pelibatan Mahkamah Konstitusi dalam melakukan perubahan (ulang) UUD 1945 yang partisipatif melalui Komisi Konstitusi? Kedua, bagaimana model pelibatan Mahkamah Konstitusi dalam perubahan (ulang) UUD 1945 yang partisipatif melalui Komisi Konstitusi?

\section{B. Metode Penelitian}

Penelitian ini adalah penelitian hukum normatif, yaitu penelitian yang dilakukan dengan cara meneliti bahan pustaka (library research). Objek penelitiannya adalah urgensi pelibatan Mahkamah Konstitusi dalam amandemen (ulang) UUD 1945 yang partisipatif melalui Komisi Konstitusi. Data yang diperlukan dalam penelitian ini adalah data sekunder yang berupa bahan-bahan hukum yang terdiri dari, bahan hukum primer, yaitu bahan hukum yang bersifat mengikat berupa Undang-Undang Dasar 1945. Di samping itu, juga digunakan bahan hukum sekunder, yang terdiri dari buku-buku literatur, jurnal, hasil penelitian dan karya ilmiah lainnya yang berhubungan dengan penelitian ini.

Dalam penelitian ini pengumpulan bahan hukum dilakukan dengan cara studi dokumen, yaitu mengkaji, menelaah dan mempelajari bahan-bahan hukum yang ada kaitannya dengan penelitian ini berupa hasil-hasil kajian komprehensif Komisi Konstitusi mengenai perubahan UUD 
1945. Penelitian ini menggunakan pendekatan konsep (conceptual approach) dan perbandingan (comparative approach), (Johny Ibrahim, 306 : 313) untuk menganalisis urgensi pelibatan Mahkamah Konstitusi dalam perubahan dan menemukan model pelibatan Mahkamah Konstitusi dalam perubahan (ulang) UUD 1945 dengan melihat praktek di beberapa negara.

\section{Hasil Penelitian dan Pembahasan}

Pembaharuan UUD di dunia ini terutama tidak ditentukan oleh tata cara resmi (formal) yang harus dilalui. Tata cara formal (fleksibel) tidak serta merta memudahkan terjadinya perubahan UUD. Begitu pula sebaliknya, tata cara formal yang dipersukar (rigid) tidak berarti perubahan UUD tidak akan atau akan jarang terjadi. Faktor utama yang menentukan perubahan UUD adalah berbagai (pembaharuan) keadaan di masyarakat. Dorongan demokratisasi, pelaksanaan paham negara kesejahteraan (welfare state), perubahan pola dan sistem ekonomi akibat industrialisasi, kemajuan ilmu pengetahuan dan teknologi dapat menjadi kekuatan (forces) pendorong pembaharuan. Jadi, masyarakatlah yang menjadi pendorong utama pembaharuan UUD. Demikian pula peranan UUD itu sendiri. Hanya masyarakat yang berkehendak dan mempunyai tradisi menghormati dan menjunjung tinggi UUD (konstitusi pada umumnya), yang akan menentukan UUD tersebut akan dijalankan sebagaimana mestinya (Jimly Ashiddiqie, 2006 : 14-15).

Wheare pernah mengingatkan, mengapa konstitusi perlu ditempatkan pada kedudukan yang tinggi (supreme), supaya ada semacam jaminan bahwa konstitusi itu akan diperhatikan dan ditaati dan menjamin agar konstitusi tidak akan dirusak dan diubah begitu saja secara sembarangan. Perubahannya harus dilakukan secara hikmat, penuh kesungguhan dan pertimbangan yang mendalam (K.C Wheare, 1975 : 7). Sasaran yang ingin diraih dengan jalan mempersulit perubahan konstitusi antara lain: a) agar perubahan konstitusi dilakukan dengan pertimbangan yang masak, tidak serampangan dan dengan sadar (dikehendaki); dan b) agar rakyat mendapat kesempatan untuk menyampaikan pandangannya sebelum perubahan dilakukan (Jimly Ashiddiqie, 2006 : 83).

UUD yang baik selalu menentukan sendiri prosedur perubahan atas dirinya sendiri. Perubahan yang dilakukan di luar prosedur yang ditentukan itu bukanlah perubahan yang dapat dibenarkan secara hukum (verfassung anderung). Inilah prinsip negara hukum yang demokratis (democratische rechtsstaat) dan prinsip negara demokrasi yang berdasarkan atas hukum (constitutional democracy) yang dicita-citakan oleh para pendiri republik kita. Di luar itu, namanya bukan 'rechtsstaat', melainkan 'machtsstaat' yang hanya menjadikan pertimbangan 'revolusi politik' sebagai landasan pembenar yang bersifat 'post factum' terhadap perubahan dan pemberlakuan suatu konstitusi (Jimly Ashiddiqie, 2001).

Menurut Sri Soemantri, apabila dipelajari secara teliti mengenai sistem perubahan konstitusi di berbagai negara, paling tidak ada dua sistem yang sedang berkembang yaitu renewel (pembaharuan) dianut di negara-negara Eropa Kontinental dan amandement (perubahan) seperti dianut di negara-negara Anglo Saxon. Sistem yang pertama ialah, apabila suatu konstitusi dilakukan perubahan (dalam arti diadakan pembaharuan), maka yang diberlakukan adalah konstitusi yang baru secara keseluruhan. Di antara negara yang menganut sistem ini misalnya: Belanda, Jerman, dan Perancis. Sistem yang kedua ialah, apabila suatu konstitusi diubah (diamandemen), maka konstitusi yang asli tetap berlaku. Dengan kata lain hasil amandemen tersebut merupakan bagian atau dilampirkan dalam konstitusinya. Sistem ini dianut oleh negara Amerika Serikat (Sri Soemantri, 1987 : 81).

Menurut Wheare, perubahan UUD akibat dorongan kekuatan (forces) yang terjadi dapat berbentuk: pertama, kekuatan-kekuatan yang kemudian melahirkan perubahan keadaan (circumstances) tanpa mengakibatkan perubahan bunyi yang tertulis dalam UUD, melainkan terjadi perubahan makna. Suatu ketentuan UUD diberi makna baru tanpa mengubah bunyinya. Kedua, kekuatan-kekuatan yang melahirkan keadaan baru itu mendorong perubahan atas ketentuan UUD, baik melalui perubahan formal (formal amandement), putusan hakim, hukum adat maupun konvensi (K.C Wheare, 1975 : 67-136).

Ada hal-hal prinsip yang harus diperhatikan dalam perubahan UUD. Menurut Bagir Manan, perubahan UUD berhubungan dengan perumusan kaidah konstitusi sebagai kaidah hukum negara tertinggi. Dalam hal ini, terlepas dari beberapa kebutuhan mendesak, perlu kehati-hatian, baik mengenai materi muatan maupun caracara perumusan. Memang benar, penataan kembali UUD 1945 untuk menjamin pelaksanaan konstitusionalisme dan menampung dinamika baru di bidang politik, ekonomi, sosial, dan lain-lain. Tapi, jangan sekali-kali perubahan itu semata-mata dijadikan dasar dan tempat untuk menampung berbagai realitas kekuatan politik yang berbeda dan sedang bersaing dalam SU MPR (Bagir Manan, 1999 : 45). 
Juga hendaknya berhati-hati dengan caracara merumuskan kaidah UUD. Selain harus mudah dipahami (zakelijk), juga menghindari kompromi bahasa yang dapat menimbulkan multitafsir yang dapat disalahgunakan di kemudian hari (Bagir Manan, 1999 : 45). Sri Soemantri menegaskan, dalam mengubah UUD harus ditetapkan dulu alasan dan tujuannya. Jika hal itu sudah disepakati, baru dapat dipikirkan langkah selanjutnya berdasarkan alasan dan tujuan perubahan itu. Misalnya, selama ini UUD terkesan terlalu berorientasi pada eksekutif. Karena itu, ditentukanlah bahwa tujuan dari perubahan UUD adalah untuk membatasi kekuasaan eksekutif. Kemudian apa yang dilakukan untuk membatasi kekuasaan eksekutif? Itu harus dipikirkan masakmasak. Misalnya, kontrol terhadap eksekutif harus diperkuat. Itu berarti kedudukan legislatif mesti diperkuat. Jadi, kita harus kembali pada alasan dan tujuan dari perubahan itu. Misalnya tujuannya adalah mewujudkan negara demokrasi, maka kita harus berbicara mengenai sistem pemerintahan (Sri Soemantri, 2001 : 14).

\section{Paradigma Perubahan UUd}

Reformasi politik dan ekonomi yang bersifat menyeluruh tidak mungkin dilakukan tanpa diiringi oleh reformasi hukum. Tetapi reformasi hukum yang menyeluruh juga tidak mungkin dilakukan tanpa didasari oleh agenda reformasi ketatanegaraan yang mendasar, dan itu berarti diperlukan adanya 'constitutional reform' yang tidak setengah hati (Jimly Ashiddiqie, 2001 : 15).

Perubahan konstitusi dipengaruhi oleh seberapa besar badan yang diberikan otoritas melakukan perubahan memahami tuntutan perubahan dan seberapa jauh kemauan anggota badan itu melakukan perubahan. Perubahan konstitusi tidak hanya bergantung pada norma perubahan, tetapi lebih ditentukan oleh kelompok elite politik yang memegang suara mayoritas di lembaga yang mempunyai kewenangan melakukan perubahan konstitusi. Lembaga yang mempunyai kewenangan melakukan perubahan harus berhasil membaca arah perubahan yang dikehendaki oleh masyarakat yang diatur secara kenegaraan.

Dalam setiap perubahan konstitusi terdapat paradigma perubahan yang harus dipatuhi oleh pembuat perubahan. Paradigma perubahan itu menjadi "politik hukum" perubahan konstitusi. Kesulitannya perubahan yang diinginkan oleh masyarakat politik tidak senantiasa sama dengan substansi perubahan yang diinginkan oleh anggota lembaga yang mempunyai kewenangan melakukan perubahan konstitusi (Ali Mukti Fajar dkk, 2004 : 39).

Perubahan konstitusi harus didasarkan pada paradigma perubahan agar perubahan terarah sesuai dengan kebutuhan yang berkembang di masyarakat. Paradigma ini digali dari kelemahan sistem bangunan konstitusi lama, dan dengan argumentasi diciptakan landasan agar dapat menghasilkan sistem yang menjamin stabilitas pemerintahan dan memajukan kesejahteraan rakyat (Ali Mukti Fajar dkk, 2004 : 85).

Paradigma itu mencakup nilai-nilai dan prinsip-prinsip penting yang mendasar atau jiwa (gheist) perubahan konstitusi. Nilai dan prinsip itu dapat digunakan untuk menyusun telaah kritis terhadap konstitusi lama dan sekaligus menjadi dasar bagi perubahan konstitusi atau penyusunan konstitusi baru. Di samping persoalan paradigma dalam perubahan konstitusi, juga perlu diperhatikan aspek teoritik dalam perubahan konstitusi yang akan mencakup masalah prosedur perubahan, mekanisme yang dilakukan, sistem perubahan yang dianut, dan substansi yang akan diubah (Ali Mukti Fajar, 2003 : 64).

Perubahan UUD 1945 yang pertama sampai dengan keempat jelas bersifat mendasar dan mencakup materi yang sangat banyak, sehingga telah mengubah sistematika, baik perumusan formalnya maupun sistematika berpikir UUD 1945. Dengan demikian, Perubahan UUD 1945 sudah tidak dapat lagi disebut menggunakan tradisi Amerika Serikat yang dijadikan rujukan dalam rangka pelaksanaan perubahan UUD 1945. Oleh karena itu, sebaiknya, teknik dan prosedur yang diacu oleh ketentuan Pasal 37 UUD 1945 itu haruslah dipahami dalam pengertian model tradisi Eropa, bukan Amerika Serikat (Bagir Manan, 2003 : 232).

Menurut Bambang Widjojanto, sejak awal sudah dapat diduga, arah dan substansi perubahan tidak akan mendasar guna mengabdi secara utuh pada kedaulatan rakyat serta membangun sistem kekuasaan yang demokratis dengan cara membenahi carut-marutnya sistem kekuasaan (Bambang Widjojanto, 2002 : 198). Menurut Denny Indrayana, pentingnya melembagakan proses reformasi konstitusi di luar institusi politik konvensional didasarkan beberapa alasan. Reformasi konstitusi yang terjadi 
sejalan dengan pergolakan politik akibat transisi dari pemerintahan otoriter, sarat benturan kepentingan politik antara kelompok status quo, yang masih membawa dan mempertahankan semangat otoriter, dengan kelompok reformis yang berusaha menuju ke negara demokratis (Guillermo O'Donnel, Philippe C. Schmitter dan Laurence Whitehead, $1986:$ 178).

Lebih Ianjut Denny Indrayana menyatakan, reformasi konstitusi yang tidak dilepaskan dari konflik politik, dengan menyerahkannya semata-mata kepada lembaga perwakilan rakyat seperti MPR, akan cenderung terkontaminasi dengan virus kompromi politik jangka pendek yang biasanya menjadi solusi pragmatis dari konflik politik transisi. Oleh karena itu, akan lebih baik bila proses reformasi konstitusi diserahkan pada lembaga profesional yang independen dan non partisan sebagaimana Komisi Konstitusi (Guillermo O'Donnel, Philippe C. Schmitter dan Laurence Whitehead, 1986 : 178).

Hal senada juga dikemukakan oleh Jimly Asshiddiqie, yang mengatakan para anggota Majelis Permusyawaratan Rakyat tidak memiliki kesempatan waktu yang memadai untuk terlebih dahulu memperdebatkan secara mendalam (Jimly Ashiddiqie, 2001 : 10). Kalaupun pilihan-pilihan konseptual yang didasarkan atas pertimbangan akademis yang matang sudah dipikirkan oleh anggota Majelis, suasana dan dinamika yang mempengaruhi proses pembahasan rancangan perubahan itu juga sangat dipengaruhi oleh kepentingankepentingan yang terlibat di dalamnya. Keadaan ini menyebabkan pilihan-pilihan yang menyangkut kebenaran akademis seringkali terpaksa dikesampingkan oleh pilihan-pilihan yang berkenaan dengan kebenaran politik. Untuk itu, yang sebaiknya merancang penyusunan kembali naskah akademik Undang-Undang Dasar adalah sebuah Panitia UUD yang dibentuk tersendiri, yang dapat dinamakan Komisi Konstitusi atau Panitia Penyusunan Undang-Undang Dasar.

Kritik tajam juga dilontarkan oleh Mukthie Fadjar, yang mengatakan dalam melakukan perubahan-perubahan terhadap UUD 1945 tersebut ternyata sejak semula MPR memang tidak memiliki visi dan misi yang jelas yang disepakati dan dirumuskan secara tegas, atau dengan kata lain tidak memiliki paradigma perubahan yang diinginkan dengan perubahan konstitusi, sehingga menuai banyak kritik baik dalam proses maupun dalam substansi, dan bahkan secara ekstrim ada dua kubu pendapat yang berhadapan secara diametral, yaitu yang menilai MPR telah 'kebablasan' dalam melakukan perubahan terhadap UUD 1945 sehingga harus dihentikan, dan yang lain menganggap MPR tidak mampu atau 'kacau balau' dalam melakukan perubahan sehingga diharapkan "melempar handuk" menyerahkan tugas perubahan atau bahkan penyusunan konstitusi baru kepada sebuah Komisi Konstitusi yang independen, sedangkan MPR hanya sebagai filternya-saja (Ali Mukti Fajar, 2003 : 59-60).

\section{Urgensi Pelibatan MK dalam Perubahan (ulang) UUd 1945}

Salah satu hasil amandemen (ketiga) UUD 1945 adalah lahirnya Pasal 24C ayat (1) yang menghadirkan lembaga baru bernama Mahkamah Konstitusi (MK). MK secara konstitusional ditentukan memiliki 4 (empat) kewenangan, yaitu: (1) menguji undang-undang terhadap Undang-Undang Dasar; (2) memutus sengketa kewenangan lembaga negara yang kewenangannya diberikan oleh Undang-Undang Dasar; (3) memutus pembubaran partai politik; (4) memutus perselisihan tentang hasil pemilihan umum. Kewenangan tersebut adalah dalam tingkat pertama dan terakhir dan putusan Mahkamah Konstitusi bersifat final, yaitu langsung mempunyai kekuatan hukum tetap dan tidak terdapat upaya hukum untuk mengubahnya. Selain wewenang itu, berdasarkan Pasal 24C ayat (2) jo Pasal 7B, Mahkamah Konstitusi juga berkewajiban untuk memeriksa, mengadili dan memutus mengenai pendapat DPR bahwa Presiden dan/atau Wakil Presiden telah melakukan pelanggaran hukum berupa pengkhianatan terhadap negara, korupsi, penyuapan, tindak pidana berat lainnya, atau perbuatan tercela, dan/atau pendapat bahwa Presiden dan/atau Wakil Presiden tidak lagi memenuhi syarat sebagai Presiden dan/atau Wakil Presiden. Perlu dicatat bahwa putusan ini sifatnya tidak final karena tunduk pada (subject to) putusan MPR, lembaga politik yang berwenang memberhentikan Presiden (Pasal 7A). Jadi berbeda dengan di Amerika Serikat yang mendahulukan proses politik daripada proses hukum (Ni'matul Huda, 2004 : 195-200).

Meskipun MK bukan lembaga parlemen, tetapi UUD 1945 telah melimpahkan 
kewenangan yang sangat signifikan kepada MK sebagai pengawal konstitusi (the guardian of the constitution) terkait dengan empat wewenang dan satu kewajiban yang dimilikinya. Hal itu membawa konsekuensi MK berfungsi sebagai penafsir konstitusi (the sole interpreter of the constitution). Konstitusi sebagai hukum tertinggi mengatur penyelenggaraan negara berdasarkan prinsip demokrasi dan salah satu fungsi konstitusi adalah melindungi hak asasi manusia yang dijamin dalam konstitusi sehingga menjadi hak konstitusional warga negara. Oleh karena itu MK juga berfungsi sebagai pengawal demokrasi (the guardian of the democracy), pelindung hak konstitusional warga negara (the protector of the citizen's constitutional rights) serta pelindung hak asasi manusia (the protector of human rights) (Ni'matul Huda, 2004 : 28).

Mekanisme peradilan konstitusi (constitution adjudication) itu sendiri merupakan hal baru yang diadopsikan ke dalam sistem konstitusional Indonesia dengan dibentuknya MK. Peradilan konstitusional itu dimaksudkan untuk memastikan bahwa UUD sungguh-sungguh dijalankan atau ditegakkan dalam kegiatan penyelenggaraan negara sehari-hari. Pengujian terhadap lembaga lain oleh lembaga yang berbeda apakah yang bersangkutan sungguhsungguh melaksanakan UUD atau tidak merupakan mekanisme yang sama sekali baru. Sebelumnya memang tidak dikenal dalam sistem hukum dan konstitusi Indonesia.

Kewenangan konstitusional MK ini adalah perwujudan prinsip checks and balances yang menempatkan semua lembaga-lembaga negara dalam kedudukan setara, sehingga dapat saling kontrol-saling imbang dalam praktek penyelenggaraan negara. Keberadaan MK jelas merupakan langkah progresif untuk mengoreksi kinerja antar lembaga negara khususnya dalam proses pendewasaan politik berbangsa dan bernegara. Melalui proses peradilan di MK, bangsa Indonesia telah meneguhkan tekad untuk menyelesaikan segala bentuk sengketa dan konflik politik melalui jalur hukum. Kita harus mulai mendisiplinkan diri menyelesaikan segala perselisihan pendapat mengenai pelaksanaan agenda demokrasi melalui jalan hukum dan konstitusi.

Setiap undang-undang yang telah disahkan pada pokoknya telah mencerminkan kehendak mayoritas rakyat Indonesia, karena
DPR dan Presiden yang telah membahas dan menyetujuinya bersama memang mendapatkan mandat langsung dari rakyat untuk menjalankan tugasnya membentuk dan mengesahkan undang-undang. Akan tetapi, undang-undang hanya mencerminkan kehendak politik DPR bersama Presiden, yang belum tentu sama dengan kehendak seluruh rakyat yang berdaulat. Kehendak seluruh rakyat tercermin dalam Undang-Undang Dasar sebagai produk MPR sebagai lembaga permusyawaratan rakyat, bukan tercermin dalam UU yang hanya mencerminkan kehendak politik DPR bersama Presiden (Jimly Ashiddiqie, 2004 : 15).

Hasil kesepakatan dalam forum politik di DPR yang ditentukan berdasarkan prinsip 'rule by majority' tidak boleh bertentangan dengan nilai-nilai dan norma keadilan yang lebih tinggi derajatnya yang terkandung dalam konstitusi. Karena itu, meskipun mayoritas rakyat menghendaki sesuatu norma hukum yang mengikat untuk umum diatur dalam suatu undang-undang, jika lembaga pengawal Undang-Undang Dasar yang bernama Mahkamah Konstitusi menilainya dalam proses peradilan sebagai hal yang bertentangan dengan konstitusi, maka norma hukum yang bersangkutan dapat dinyatakan tidak boleh mengikat untuk umum. Suara mayoritas berdasarkan prinsip demokrasi betapapun juga tidak boleh mengabaikan prinsip-prinsip nomokrasi, meskipun hanya didukung oleh minoritas suara. Karena pada akhirnya, suara minoritas keadilan itulah yang sungguh-sungguh mencerminkan suara seluruh rakyat yang berdaulat (Jimly Ashiddiqie, 2004 : 15).

Selama hampir 10 (sepuluh) tahun berdirinya, MK telah menjalankan dan melaksanakan tiga macam perkara yang menjadi kewenangannya, yaitu menguji undang-undang terhadap Undang-Undang Dasar, memutus sengketa kewenangan lembaga negara yang kewenangannya diberikan oleh Undang-Undang Dasar, memutus perselisihan tentang hasil pemilihan umum. Mahkamah belum pernah memutus pembubaran partai politik dan memberikan putusan mengenai pendapat DPR bahwa Presiden dan/atau Wakil Presiden telah melakukan pelanggaran hukum berupa pengkhianatan terhadap negara, korupsi, penyuapan, tindak pidana berat lainnya, atau perbuatan tercela, dan/atau pendapat bahwa Presiden dan/atau Wakil Presiden tidak lagi 
memenuhi syarat sebagai Presiden dan/atau Wakil Presiden.

Sebagai lembaga negara produk reformasi, MK menjadi tumpuan ekspektasi masyarakat yang menginginkan terjadinya perbaikan dalam bidang penegakan hukum. Sejauh ini MK telah merespons harapan publik tersebut melalui proses peradilan yang bersih dan putusan yang menjunjung tinggi prinsip keadilan (Moh Mahfud MD, 2009 : vii). Terkait dengan penegakan prinsip keadilan ini, MK mengedepankan keadilan substantif, yaitu keadilan yang lebih didasarkan pada kebenaran material daripada kebenaran formal-prosedural. Dengan kata lain, apa yang secara formal-prosedural benar bisa saja disalahkan jika secara material dan substansinya melanggar keadilan. Sebaliknya apa yang secara formal-prosedural salah bisa saja dibenarkan jika secara material dan substansial sudah cukup adil.

MK menekankan perlunya keadilan substantif untuk menghindari munculnya putusan yang mengabaikan rasa keadilan sebagaimana kerap ditemukan dalam putusan pengadilan pada masa lalu. Terobosan hukum tersebut perlu dilakukan untuk menggairahkan penegakan hukum dalam masyarakat (Moh Mahfud MD, 2009 : vii). Diakui sudah banyak kemajuan-kemajuan yang dicapai oleh institusi kehakiman ini. MK sudah membuktikan sebagai institusi hukum yang dapat dipercaya dan terhormat (reliable and honoured court) di Indonesia. Hal ini dibuktikan dengan banyaknya putusanputusan MK yang sangat progresif dan dapat menjadi acuan hukum bagi percepatan reformasi hukum di Indonesia.

Meskipun MK sudah sangat produktif memeriksa dan memutus perkara judicial review, tidak sedikit masyarakat yang sering terusik oleh beberapa putusan MK yang dipandang kontroversial, yakni putusanputusan dalam pengujian Undang-Undang yang bersifat ultra petita, bahkan ada kesan MK bukan hanya bertindak sebagai negative legislator tetapi juga sudah memasuki area positive legislator.

Semula putusan MK hanya sekedar menyatakan suatu norma atau undangundang bertentangan terhadap UndangUndang Dasar, kemudian berkembang dengan memberikan tafsir suatu norma atau undang-undang yang diuji agar memenuhi syarat konstitusionalitas sehingga tidak terhindarkan MK membuat norma baru. Dalam beberapa putusannya MK telah melakukan pengujian atas produk legislasi sehingga norma atau undang-undang yang diuji memenuhi syarat konstitusionalitas. Putusan MK memberi tafsir (petunjuk, arah, dan pedoman serta syarat bahkan membuat norma baru) yang dapat diklasifikasi sebagai putusan konstitusional bersyarat (conditionally constitutional) dan putusan inkonstitusional bersyarat (conditionally unconstitutional)( Hamdan Zoelva, 2011).

Jika tafsir yang ditentukan dalam putusan MK dipenuhi maka suatu norma atau undang-undang tetap konstitusional sehingga dipertahankan legalitasnya. Adapun jika tafsir yang ditentukan dalam putusan MK tidak dipenuhi maka suatu norma hukum atau undang-undang menjadi inkonstitusional sehingga harus dinyatakan bertentangan dengan Undang-Undang Dasar dan tidak mempunyai kekuatan hukum mengikat (Hamdan Zoelva, 2011).

Dari uraian di atas, dengan melihat posisi strategis MK sebagai pengawal konstitusi (the guardian of the constitution), penafsir konstitusi (the sole interpreter of the constitution), pengawal demokrasi (the guardian of the democracy), pelindung hak konstitusional warga negara (the protector of the citizen's constitutional rights) serta pelindung hak asasi manusia (the protector of human rights), kiranya sudah tepat jika MK dilibatkan dalam proses perubahan konstitusi yang partisipatif oleh Komisi Konstitusi. Apalagi konstitusi (UUD 1945 hasil perubahan ulang) tersebut nantinya akan dipergunakan oleh MK untuk menguji UU yang dibuat oleh DPR dan Pemerintah.

\section{Alternatif Model Perubahan Konstitusi}

Sebelum dilakukan amandemen terhadap Pasal 37 UUD 1945, mekanisme perubahan UUD 1945 sangatlah sederhana pengaturannya. Untuk mengubah UUD sekurang-kurangnya 2/3 dari pada jumlah anggota MPR harus hadir. Putusan diambil dengan persetujuan sekurang-kurangnya 2/3 dari pada jumlah anggota yang hadir. Akan tetapi, setelah adanya amandemen UUD 1945, mekanisme perubahan UUD sebagaimana yang diatur dalam Pasal 37 UUD 1945 nampak semakin dipersulit. Hal itu terbukti dari gagalnya usulan amandemen ulang yang diusung oleh DPD RI selama ini karena tidak tercapainya quorum MPR. Pasal 37 UUD 1945 hasil amandemen menentukan sebagai berikut. 
a. Usul perubahan pasal-pasal UUD dapat diagendakan dalam sidang MPR apabila diajukan oleh sekurang-kurangnya 1/3 dari jumlah anggota MPR

b. Setiap usul perubahan pasal-pasal UUD diajukan secara tertulis dan ditunjukkan dengan jelas bagian yang diusulkan untuk diubah beserta alasannya.

c. Untuk mengubah pasal-pasal UUD, Sidang MPR dihadiri oleh sekurangkurangnya 2/3 dari jumlah anggota MPR.

d. Putusan untuk mengubah pasal-pasal UUD dilakukan dengan persetujuan sekurang-kurangnya lima puluh persen ditambah satu anggota dari seluruh anggota MPR.

e. Khusus mengenai bentuk Negara Kesatuan Republik Indonesia tidak dapat dilakukan perubahan.

Pasal 37 tersebut membuka ruang dimunculkannya usul perubahan dan tidak membatasi siapa yang menyusun draf usulan perubahannya. Meskipun pembatasanpembatasan quorum MPR tersebut dalam prakteknya bisa menjadi kendala tersendiri jika usulan perubahan tidak didukung oleh mayoritas anggota MPR.

Ada kekhawatiran dari sejumlah kalangan, kalau amandemen UUD kembali diserahkan kepada MPR maka akan terjadi conflict of interest sebagaimana yang sudah terjadi pada amandemen pertama s/d keempat (1999-2002). Untuk itu diusulkan dibentuknya lembaga independen yang dipilih oleh rakyat - semacam Badan Konstituante (Konstitusi Republik Indonesia Serikat 1949 dan UUD Sementara 1950) yang dibentuk khusus untuk melakukan perubahan UUD atau yang banyak digunakan di berbagai negara dengan sebutan Komisi Konstitusi.

Dalam sejarah ketatanegaraannya, Pemerintah Indonesia pernah memiliki Badan Konstituante ketika berlakunya Konstitusi RIS 1949 dan UUD Sementara 1950 yang diberi mandat khusus untuk melakukan penyusunan UUD. Dalam Pasal 186 Konstitusi RIS ditegaskan, "Konstituante (Sidang Pembuat UUD) bersama-sama dengan pemerintah selekas-lekasnya menetapkan Konstitusi RIS yang akan menggantikan Konstitusi sementara ini." Kemudian dalam Pasal 187 KRIS ditegaskan: (1) Rancangan Konstitusi dibuat oleh Pemerintah dan dengan amanat Presiden disampaikan kepada Konstituante untuk di musyawarahkan, demi sidang itu berapat. (2) Pemerintah menjaga, supaya rancangan Konstitusi berdasarkan pembangunan RIS dari negara-negara sesuai dengan kehendak rakyat, sebagai yang akan dinyatakan dengan cara demokrasi menurut yang ditetapkan dalam Pasal 43 sampai dengan 46. (3) Berkenaan dengan menjalankan yang ditetapkan dalam pasalpasal yang tersebut dalam ayat yang lalu, Undang-Undang Federal akan mengadakan tindakan-tindakan yang perlu, sehingga pernyataan suara rakyat yang diperlukan diperoleh dalam satu tahun sesudah Konstitusi ini mulai berlaku.

Selanjutnya dalam Pasal 188 KRIS ditentukan: (1) Konstituante dibentuk dengan jalan memperbesar DPR yang dipilih menurut Pasal 111 dan Senat baru yang ditunjuk menurut Pasal 97, dengan anggota-anggota luar biasa sebanyak jumlah anggota luar biasa itu dipilih ataupun ditunjuk atau diangkat dengan cara yang sama sebagai anggota biasa. Pemerintah mengadakan persediaan, sekadar perlu dengan mufakat dengan daerah-daerah bagian, untuk menjamin supaya anggota-anggota luar biasa DPR dan Senat dipilih, diangkat ataupun ditunjuk pada waktunya. (2) Rapat gabungan DPR dan Senat, keduanya dengan jumlah anggota dua kali lipat, itulah Konstituante. (3) Ketua DPR ialah Ketua Konstituante, Ketua Senat ialah Wakil Ketua. (4) Yang ditetapkan dalam Pasal 87, 93, 94 ayat (3) dan (4), 95 dan 105, berlaku demikian juga bagi Konstituante. (5) Rapat-rapat Konstituante terbuka bagi umum, kecuali jika dianggap perlu oleh Ketua menutup pintu ataupun jika sekurangkurangnya 25 anggota menuntut hal itu.

Di dalam Pasal 189 KRIS ditegaskan: (1) Konstituante tidak dapat bermufakat atau mengambil keputusan tentang rancangan Konstitusi baru, jika pada rapatnya tidak hadir $2 / 3$ dari jumlah anggota sidang. (2) Konstituante berhak mengadakan perubahanperubahan dalam rancangan Konstitusi. Konstitusi baru berlaku, jika rancangannya telah diterima dengan sekurang-kurangnya 2/3 dari jumlah suara anggota yang hadir dan kemudian disahkan oleh Pemerintah. (3) Apabila Konstituante sudah menerima rancangan Konstitusi, maka dikirimkannya rancangan itu kepada Presiden untuk disahkan oleh Pemerintah. Pemerintah harus mengesahkan rancangan itu dengan segera. Pemerintah mengumumkan Konstitusi itu dengan keluhuran. (4) Kepada tiap-tiap 
negara bagian akan diberikan kesempatan menerima Konstitusi. Dalam hal suatu negara bagian tidak menerima Konstitusi itu, maka negara itu berhak bermusyawarah tentang suatu perhubungan khusus dengan RIS dan kerajaan Nederland.

Demikian pula ketika Konstitusi RIS diganti dengan UUD Sementara 1950, Konstituante (Sidang Pembuat UUD) kembali diatur. Di dalam Pasal 134 UUDS 1950 ditegaskan "Konstituante (Sidang Pembuat UUD) bersama-sama dengan pemerintah selekas-lekasnya menetapkan UUD RI yang akan menggantikan UUD Sementara ini." Pasal ini ramai diperdebatkan dalam Konstituante untuk menentukan penafsiran autentik dari kata-kata "bersama-sama dengan" yang terdapat dalam pasal pertama, karena kata-kata tersebut tidak menjelaskan batas-batas peran pemerintah (Adnan Buyung Nasution, 1995 : 35). Konstituante menentukan bahwa kata-kata "bersamasama dengan" seharusnya ditafsirkan dalam kaitannya dengan Pasal 137 ayat (3) yang berbunyi: "Apabila Konstituante sudah menerima rancangan UUD, maka dikirimkannya rancangan itu kepada Presiden untuk disahkan oleh Pemerintah. Pemerintah mengesahkan rancangan itu dengan segera. Pemerintah mengumumkan UUD itu dengan keluhuran."

Pasal ini menunjukkan bahwa peran pemerintah baru mulai sesudah Konstituante menyetujui rancangan undang-undang dasar. Karena itu, melalui tafsiran sistematis, Konstituante menyimpulkan bahwa peran pemerintah sangat terbatas, tidak lebih dari mensahkan dan mengumumkan undangundang dasar baru yang seluruhnya dibuat oleh Konstituante. Pasal terakhir ini menetapkan bahwa sesudah rancangan undangundang dasar disetujui oleh Konstituante, pemerintah harus segera mensahkan dan mengumumkannya "dengan keluhuran" (Adnan Buyung Nasution, 1995 : 35).

Selanjutnya Pasal 135 menentukan sebagai berikut: "(1) Konstituante terdiri dari sejumlah anggota yang besarnya ditetapkan berdasarkan atas perhitungan setiap 150.000 jiwa penduduk WNI mempunyai seorang wakil. (2) Anggota-anggota Konstituante dipilih oleh WNI dengan dasar umum dan dengan cara bebas dan rahasia menurut aturan-aturan yang ditetapkan dengan UU. (3) Ketentuan-ketentuan dalam Pasal 58 berlaku buat Konstituante dengan pengertian bahwa jumlah-jumlah wakil itu dua kali lipat." Ketentuan-ketentuan di dalam UUDS 1950 di atas menegaskan kedudukan Konstituante sebagai satusatunya badan yang berwenang menyusun UUD, sebagai forum bagi wakil-wakil rakyat yang dipilih secara langsung dalam pemilihan yang bebas dan rahasia dengan tujuan merancang undang-undang dasar baru.

Menarik disimak pengakuan Presiden Soekarno pada waktu pelantikan anggota Konstituante tanggal 10 November 1956, yang secara tersirat mengakui akan mandat dan wewenang tunggal Badan Konstituante sebagai berikut (Adnan Buyung Nasution, 1995 : 36).

"Kita bukan tidak punya konstitusi, malah dengan konstitusi yang berlaku sekarang, kita sudah mempunyai tiga konstitusi... Tapi semua konstitusi (1945, 1949, dan 1950) dari yang nomor satu sampai dengan nomor tiga itu adalah bersifat sementara. Dan semua konstitusi itu bukanlah hasil permusyawaratan antara anggota-anggota sesuatu konstituante yang dipilih langsung oleh rakyat dalampemilihan umum yang bebas dan rahasia. Semua konstitusi itu adalah buatan sarjana konstitusi, atas amanat Pemerintah. Tetapi sesuatu negara hukum yang demokratis menghendaki sebagai syarat mutlak sebuah konstitusi yang dibuat oleh tangan rakyat sendiri."

Walaupun Badan Konstituante telah terbentuk dan sudah melakukan mandatnya untuk menyiapkan konstitusi baru yang akan menggantikan UUD 1945, tetapi suasana politik ketika itu tidaklah mendukung kinerja Badan Konstituante untuk menyelesaikan tugas besar yang disandangnya. Kerja Badan Konstituante justru dihentikan dengan tragis oleh Pemerintah karena Soekarno mengeluarkan Dekrit Presiden 5 Juli 1959, yang memerintahkan untuk membubarkan Badan Konstituante dan kembali ke UUD 1945.

Sejarah berulang ketika hasil amandemen UUD 1945 'digugat' oleh masyarakat karena hasilnya belum optimal. Masyarakat menuntut agar hasil amandemen UUD 1945 dikaji ulang dan disempurnakan oleh lembaga yang independen di luar MPR. Pada Sidang Tahunan MPR RI 2002, Minggu 11 Agustus 2002 pukul 01.30 dini hari, seluruh fraksi sepakat untuk membentuk Komisi Konstitusi dengan landasan hukum Ketetapan MPR, yakni Ketetapan MPR No. I/MPR/2002 tentang Pembentukan Komisi Konstitusi dengan mandat mengkaji secara komprehensif UUD 1945 dan perubahannya. 
Untuk menindaklanjuti perintah dari Ketetapan MPR No. I/MPR/2002 tersebut, dalam Sidang Tahunan MPR RI tahun 2003 lahir Keputusan MPR RI No. Iv/MPR/2003 tentang Susunan, Kedudukan, Kewenangan, dan Keanggotaan Komisi Konstitusi. Di dalam Pasal 1 Keputusan MPR RI No. Iv/MPR/2003 ditegaskan bahwa tugas Komisi Konstitusi adalah melakukan pengkajian secara komprehensif terhadap UUD 1945 dalam waktu 7 (tujuh) bulan (Krishna Harahap, 2004, 155). Secara etimologis, pengkajian secara komprehensif dapat diartikan mempelajari, menyelidiki, menguji, menelaah, memikirkan secara luas dan lengkap tentang Perubahan UUD 1945.

Dalam melaksanakan tugasnya Komisi Konstitusi berwenang untuk, (1)Memperoleh seluruh bahan dan risalah mengenai Perubahan UUD Negara RI Tahun 1945; (2)Memperoleh penjelasan mengenai latar belakang dan proses Perubahan UUD Negara RI Tahun 1945 dan anggota Badan Pekerja MPR RI; (3)Melakukan penelitian dan analisis hasil Perubahan UUD Negara RI Tahun 1945.

Dalam melaksanakan tugasnya Komisi Konstitusi berpedoman pada Pembukaan UUD Negara RI Tahun 1945, dan melakukan pengkajian secara transparan dengan melibatkan masyarakat luas. Di samping itu, dalam melakukan pengkajian, Komisi Konstitusi terikat kepada kesepakatan dasar PAH I MPR yang menyatakan: 1. Tidak mengubah Pembukaan UUD 1945. 2. Tetap mempertahankan Negara Kesatuan Republik Indonesia. 3. Mempertegas sistem pemerintahan presidensiil. 4. Penjelasan UUD 1945 ditiadakan serta hal-hal normatif dalam Penjelasan dimasukkan ke dalam pasal-pasal. 5. Perubahan dilakukan dengan cara "adendum".

Susunan Komisi Konstitusi terdiri atas anggota dan pimpinan yaitu seorang Ketua, dua orang Wakil Ketua, seorang Sekretaris dan seorang Wakil Sekretaris masing-masing merangkap sebagai anggota, yang dipilih dari dan oleh anggota. Komisi Konstitusi bertanggungjawab kepada MPR RI melalui Badan Pekerja MPR RI.

Anggota Komisi Konstitusi diisyaratkan memiliki wawasan kebangsaan dan sikap kenegarawanan serta memiliki kemampuan untuk melakukan pengkajian UUD Negara RI Tahun 1945. Anggota Komisi Konstitusi berjumlah 31 (tiga puluh satu) orang dipilih oleh Badan Pekerja MPR
RI, yang pemilihannya dilakukan secara transparan dan partisipatif dan ditetapkan oleh Pimpinan MPR RI. Anggota Komisi Konstitusi ditetapkan selambat-lambatnya 60 (enam puluh) hari setelah Keputusan ini ditetapkan. Masa kerja Komisi Konstitusi adalah 7 (tujuh) bulan terhitung sejak tanggal penetapan Anggota Komisi Konstitusi.

Dalam merumuskan hasil pengkajian tidak dilakukan pemungutan suara. Seluruh hasil kajian tersebut disampaikan oleh Komisi Konstitusi kepada Badan Pekerja MPR RI, untuk selanjutnya dilaporkan dalam sidang terakhir MPR RI periode 1999-2004. Komisi Konstitusi yang dibentuk oleh MPR ternyata tidak diberi tugas dan kewenangan yang signifikan untuk menyempurnakan hasil perubahan UUD 1945 yang masih carut-marut. Lahirnya Keputusan MPR No. Iv/MPR/2003 belum cukup menjawab keresahan masyarakat terhadap hasil yang diperoleh MPR dalam melakukan perubahan UUD 1945. Keputusan MPR tersebut hanyalah 'ikhtiar setengah hati' dari MPR dalam merespon tuntutan kekecewaan masyarakat terhadap hasil perubahan UUD 1945. Atau kelahiran Komisi Konstitusi sesungguhnya tidak dikehendaki oleh MPR, karena MPR berpendapat bahwa penetapan dan perubahan UUD adalah monopoli MPR (Ni'matul Huda, 2007 : 213).

Kegagalan demi kegagalan badan atau komisi yang mendapatkan mandat untuk menyiapkan perubahan konstitusi yang dialami oleh Indonesia menjadi pelajaran yang sangat berharga bagi perjalanan ketatanegaraan Indonesia. Untuk itu, perlu untuk melakukan komparasi dengan beberapa negara mengenai model perubahan konstitusi yang dipraktekkan oleh negara-negara lain yang bisa dijadikan acuan dalam melakukan perubahan (ulang) UUD 1945. Misalnya dengan melihat pengalaman negara lain yang telah sukses membentuk Komisi Konstitusi untuk menyiapkan perubahan konstitusi. Pengalaman Filipina yang di bawah Corazon Aquino membentuk constitutional commission, Thailand yang membuat constitutional drafting Assembly, dan Afrika Selatan membentuk constitution Assembly, yang menunjukkan bahwa penyerahan perubahan konstitusi kepada lembaga semacam Komisi Konstitusi, akan lebih menjamin suksesnya reformasi konstitusi.
1. Popular Ratification of Constitution
Model ini langsung melibatkan masyarakat pemilih. Darimana pun 
lembaga legislatif memperoleh masukan atas rancangan perubahan konstitusi, atau konstitusi baru sama sekali, tetapi dokumen itu harus mendapatkan persetujuan masyarakat pemilih (Referendum - Korea Selatan, 1987 dan Plebisit di Philipina, 1987) (Bambang Widjojanto, 2002 : 212).

2. constitutional convention (Bambang Widjojanto, 2002 : 212).

a. Lembaga legislatif menyiapkan rancangan perubahan konstitusi lalu mengundang rapat besar (konvensi) yang dihadiri utusan daerah-daerah. Utusan Daerah ini khusus dipilih di daerah guna menghadiri konvensi. Para utusan ini membahas, menolak, mengubah, dan menyetujui rancangan yang disiapkan lembaga legislatif Cara ini diadopsi dalam Konstitusi Philipina 1987 (Article XVII Section 3).

b. Konvensi yang menyiapkan rancangan untuk disodorkan kepada lembaga legislatif (Model Amerika Serikat ketika mengubah Articles of confederation 1777 dan menggantinya dengan Konstitusi AS). Rancangan hasil konvensi konstitusi disodorkan kepada Kongres AS, dan diratifikasi negaranegara bagian (1787-1790).

3. constitutional Initiatives (Swiss, 1892) (Bambang Widjojanto, 2002 : 212-213).

Pola ini diadopsi di Swiss sejak tahun 1892, yang kemudian diikuti banyak negara bagian di Amerika Serikat. Cara ini mengasumsikan kepedulian politik warga negara yang terhitung tinggi, tradisi baca tulis yang telah maju, sarana dan prasarana komunikasi memadai, jumlah penduduk tidak banyak, dan wilayah negara tidak menjadi hambatan. Cara ini bukan dimaksudkan untuk menyusun konstitusi baru, tetapi hanya untuk menghasilkan amandemen konstitusi. Dibedakan menjadi 2: (a) Unformulated (gagasan kepada lembaga legislatif agar mengubah konstitusi, (b) Formulated initiatives (rumusan amandemen konstitusi).

4. constitutional Assembly (Afrika Selatan)

Mandat kepada anggota constitutional Assembly (Majelis Konstitusi) adalah menghadirkan konstitusi baru. Sebelum dilakukan reformasi konstitusi, ditetapkan dulu Interim constitution (Konstitusi Sementara). Interim constitution mencantumkan 34 prinsip-prinsip dasar (constitutional principles) yang harus dijadikan patokan penyusunan konstitusi baru, menyangkut konsep dasar konstitusi demokratis (kemandirian kekuasaan kehakiman, perlindungan HAM dan sistem kontrol antar lembaga negara).

Interim constitution menentukan bahwa hasil akhir konstitusi constitutional Assembly sebelum disahkan menjadi UUD harus mendapatkan proses sertifikasi lebih dahulu dari Mahkamah Konstitusi. Mahkamah Konstitusi memeriksa apakah konstitusi yang disiapkan constitutional Assembly bertentangan atau tidak dengan constitutional principles yang ada dalam Interim constitution. Hasilnya, setelah dua kali diajukan barulah constitutional Assembly memberikan sertifikasi (Jimly Ashiddiqie, 2006 : 283).

5. constitutional drafting Assembly (Thailand), (Jimly Ashiddiqie, 2006 : 179-180)

Reformasi konstitusi oleh lembaga khusus itulah yang menjadi salah satu penentu keberhasilan Thailand melahirkan konstitusi baru yang akhirnya disebut The people constitution. Sebutan itu begitu melekat karena hasil reformasi konstitusi yang dipelopori constitutional drafting Assembly amat berbeda dengan lima belas konstitusi Thailand sebelumnya yang begitu elitis dan amat dipengaruhi kekuatan militer.

constitutional drafting Assembly beranggotakan 76 orang perwakilan provinsi dan 23 orang dari berbagai perguruan tinggi di Thailand, khususnya mempersiapkan rancangan konstitusi dan menyebarluaskannya kepada rakyat Thailand. Sosialisasi dilakukan secara amat terbuka dengan memperbanyak public hearing yang diselenggarakan oleh cabang-cabang constitutional drafting Assembly di daerah-daerah untuk menyaring sebanyak mungkin aspirasi rakyat Thailand.

Melalui proses reformasi konstitusi di constitutional drafting Assembly inilah akhirnya tahun 1997 The people constitution disahkan parlemen Thailand dan dianggap sukses mengakhiri krisis 
konstitusi yang sudah berlangsung lebih dari 65 tahun sejak berlakunya konstitusi pertama Thailand (1932) hingga konstitusinya yang ke lima belas (1997).

Dengan melihat kembali desain Komisi Konstitusi yang pernah dibentuk oleh MPR dengan kewenangan yang sangat 'minim', ke depan, perlu dibentuk Komisi Konstitusi yang diberi mandat untuk melakukan amandemen (ulang) yang melibatkan MK untuk penyempurnaan hasil akhirnya. Komisi Konstitusi yang akan dibentuk harus diberi kewenangan yang signifikan sebagaimana yang dipraktekkan di beberapa negara yang telah sukses menyusun konstitusi baru. Di samping itu, Komisi Konstitusi wajib steril dari keanggotaan partai politik. Keikutsertaan partai politik dalam perubahan konstitusi, akan menyebabkan hasil perubahan konstitusi tidak maksimal.

Larangan aktifnya partai politik dalam Komisi Konstitusi dapat didasarkan pada filosofi eksisnya konstitusi yang amat bertolak belakang dengan partai politik. Filosofi konstitusi adalah untuk membatasi penguasa dan kekuasaan negara. Sebaliknya, filosofi partai politik adalah untuk merebut dan menguasai sebanyak mungkin posisi penguasa dan kekuasaan negara. Karena filosofi yang amat berbeda itu, maka proses perubahan konstitusi harus dipisahkan dari partai politik agar tidak menimbulkan conflict of interest.

Bagaimana pelibatan MK dalam perubahan (ulang) UUD 1945? MK tidak dilibatkan sejak perumusan awal draf perubahan UUD. Perumusan draf perubahan (ulang) serta penyebaran atau pun penyerapan aspirasi masyarakat terhadap draf tersebut dilakukan oleh Komisi Konstitusi. Apabila draf perubahan (ulang) sudah disetujui oleh masyarakat, Komisi Konstitusi wajib meminta pendapat MK apakah draf perubahan tersebut bertentangan atau tidak dengan prinsip-prinsip yang disepakati oleh MPR sebelum dilakukan. Apabila MK memandang draf tersebut sudah sesuai dengan prinsip-prinsip kenegaraan Indonesia, barulah draf tersebut diajukan kepada MPR untuk dimintakan persetujuan.
Sebagaimana yang dipraktekkan di Afrika Selatan, hasil akhir konstitusi yang disiapkan oleh Komisi Konstitusi (constitutional Assembly) sebelum disahkan menjadi UUD harus mendapatkan proses sertifikasi lebih dahulu dari Mahkamah Konstitusi. Mahkamah Konstitusi memeriksa apakah konstitusi yang disiapkan Komisi Konstitusi bertentangan atau tidak dengan constitutional principles yang ada dalam Interim constitution. Hasilnya, setelah dua kali diajukan barulah constitutional Assembly memberikan sertifikasi.

Untuk meningkatkan partisipasi masyarakat dalam penyusunan konstitusi ataupun perubahan (ulang) UUD 1945, dapat berkaca dari model yang dilakukan oleh constitutional drafting Assembly di Thailand. Sosialisasi draf konstitusi dilakukan secara amat terbuka dengan memperbanyak public hearing yang diselenggarakan oleh cabang-cabang constitutional drafting Assembly di daerah-daerah untuk menyaring sebanyak mungkin aspirasi rakyat Thailand.

\section{d. Simpulan}

Dari uraian analisis atas permasalahan dalam penelitian ini, dapat disimpulkan sebagai berikut. pertama, Mahkamah Konstitusi perlu dilibatkan dalam perubahan UUD 1945 karena UUD 1945 akan dijadikan sebagai batu uji oleh MK dalam melakukan wewenangnya menguji undangundang, sehingga perlu memberikan penilaian apakah secara substantif materi muatan konstitusi antar pasalnya sinkron, tidak overlapping, dan lain-lain. Kedua, bentuk pelibatan MK dalam hal memberikan sertifikasi atas draf yang sudah disusun oleh Komisi Konstitusi dan setelah mendapatkan persetujuan mayoritas rakyat. Sehingga draf perubahan konstitusi yang sudah mendapat sertifikasi dari MK tinggal disahkan oleh MPR.

Untuk itu ke depan, perlu dibentuk Komisi Konstitusi yang independen dan kredibel untuk melakukan perubahan (ulang) UUD 1945 agar menjadi lebih sempurna. Di samping itu, dalam melakukan perubahan perlu melibatkan partisipasi masyarakat sebanyak mungkin input dihimpun dan melibatkan MK dalam proses sertifikasinya. MPR tidak lagi diberi kewenangan untuk merubah UUD, tetapi cukup diserahkan kepada Komisi Konstitusi, MPR tinggal mengesahkan draf yang sudah mendapatkan sertifikasi dari MK. 


\section{daftar Pustaka}

A. Mukthie Fadjar, reformasi Konstitusi dalam Masa Transisi paradigmatik, In-TRANS, Malang, 2003.

A. Mukthie Fadjar dan Harjono (editor), pembaharuan Ketatanegaraan Melalui perubahan Konstitusi, In-TRANS, Malang, 2004.

Adnan Buyung Nasution, Aspirasi pemerintahan Konstitusional di Indonesia, Studi Sosio-Legal atas Konstituante 1956-1959, Pustaka Utama Grafiti, Jakarta, 1995.

Bagir Manan, Teori dan politik Konstitusi, FH UII Press, Yogyakarta, 2003.

Bambang Widjojanto dkk. (Editor), Konstitusi Baru Melalui Komisi Konstitusi Independen, Pustaka Sinar Harapan,Jakarta, 2002.

Guillermo O'Donnel, Philippe C. Schmitter dan Laurence Whitehead (Editor), Transition from Authoritarian rule: prospect for democracy, 1986.

Hamdan Zoelva, "Mekanisme checks and Balances Antar Lembaga negara (Pengalaman dan Praktik Di Indonesia)", makalah disampaikan pada Simposium Internasional "Negara demokrasi Konstitusional", yang diselenggarakan dalam rangka ulang tahun ke-8 Mahkamah Konstitusi RI, Jakarta, Selasa 12 Juli 2011.

Jimly Asshiddiqie, "Telaah Akademis Atas Perubahan UUD 1945", Jurnal demokrasi \& HAM, vol. 1, No. 4, September-November 2001.

, "Konsolidasi Materi Undang-Undang Dasar Republik Indonesia", Kuliah Perdana Program Magister IImu Hukum Universitas Islam Indonesia, Yogyakarta, 13 September 2001.

Jimly Asshiddiqie dan Bagir Manan, dkk., gagasan Amandemen UUd 1945 dan pemilihan presiden Secara Langsung, Sebuah dokumen Historis, Sekretariat Jenderal \& Kepaniteraan Mahkamah Konstitusi, Jakarta, 2006.

Jimly Asshiddiqie dan Ahmad Syahrizal, peradilan Konstitusi di Sepuluh Negara, Konstitusi Press, Jakarta, 2006.

Johnny Ibrahim, Teori \& Metodologi penelitian Hukum Normatif, Cetakan Kedua, Bayumedia, Malang, 2006.

K.C. Wheare, Modern constitution, Oxford University Press, New York - Toronto - London, Third Impression, 1975.

Komisi Konstitusi, Buku I Naskah Akademik Kajian Komprehensif Komisi Konstitusi tentang perubahan UUd Negara republik Indonesia Tahun 1945, MPR RI, Jakarta, 2004.

Krisna Harahap, Konstitusi republik Indonesia Sejak proklamasi Hingga reformasi, PT Grafitri Budi Utami, Jakarta, 2004.

Mahkamah Konstitusi RI, "Menuju Peradilan Modern \& Terpercaya”, Laporan Tahunan Mahkamah Konstitusi $\boldsymbol{r l}$, Jakarta, 2006.

Ni'matul Huda, politik Ketatanegaraan Indonesia Kajian Terhadap dinamika perubahan UUd 1945, Cetakan Kedua, FH UII Press, Yogyakarta, 2004 Lembaga Negara dalam masa Transisi demokrasi, UII Press, Yogyakarta, 2007. , UUd 1945 dan gagasan Amandemen Ulang, Rajawali Pers, Jakarta, 2008.

Sri Soemantri M., prosedur dan Sistem perubahan Konstitusi, Alumni, Bandung, 1987.

Forum Keadilan, No.30, 31 Oktober 1999

Forum Keadilan, No. 14, 8 Juli 2001.

Kompas, 31 Januari 2008.

Kompas, 1 Pebruari 2008.

Undang-Undang Dasar Negara Republik Indonesia Tahun 1945 